\title{
The Asian Contribution to the Development of International Law: Focusing on the ReCAAP
}

\author{
Makoto Seta*
}

1 Introduction: Development of International Law in Asia

Although international law is universally applied, it has been criticised on account that it was established by Western States based on Western values. ${ }^{1}$ Aside from the validity of such criticism, it is undeniable that most rules of international law originate from European values and experiences. A testament to this is the fact that most provisions in the International Covenant on Civil and Political Rights, a universal human rights treaty, are similar to those of the European Convention on Human Rights and Fundamental Freedoms, which was adopted in Europe almost fifteen years before the universal treaty. ${ }^{2}$ Furthermore, international criminal law, particularly the crime of genocide, was developed from the European experience of the Holocaust. ${ }^{3}$

Meanwhile, compared to Europe, other regions have only provided a limited contribution to the development of international law. In particular, in the case of Asia, there seem to be two grounds on which such insufficient contribution originates. First, since it is challenging to define Asia and determine which states belong to it, ${ }^{4}$ the Asian region seems to entail both vagueness and variety. Therefore, it is difficult to perceive Asian regional contributions, aside from contributions by some Asian States or experts. Second, as sovereignty plays a more critical role in Asian States, ${ }^{5}$ the rules of international law that by

* Yokohama City University.

1 E.g., Mohammed Bedjaoui, Towards a New International Economic Order 141 (1979).

2 See, e.g., Ed Bates, The Evolution of the European Convention on Human Rights: From its inception to the Creation of a Permanent Court of Human Rights 39 (2010).

3 William A. Schabas, Genocide in International law: The Crime of Crimes 17-52 (2d ed. 2009).

4 Asian Development Bank, Emerging Asian Regionalism: A Partnership for ShARED Prosperity 24 (2008), https://www.adb.org/sites/default/files/publication/159353/ adbi-emerging-asian-regionalism.pdf (noting that "Asia's geographical boundaries are not generally agreed").

5 Motoo Noguchi, Criminal Justice in Asia and Japan and the International Criminal Court, 6 International Criminal LaW Review 585, 589-9o (2006). 
nature enshrine States' sovereignty cannot be introduced and employed in the same manner as in the European region.

Given this reality, it is startling that a treaty established in the Asian region could significantly influence the development of international law, as in the case of the Regional Cooperation Agreement on Combating Piracy and Armed Robbery against Ships in Asia (ReCAAP). Taking this context into account, this article examines the contribution of the ReCAAP in the development of international law. For this purpose, section 2 outlines the background of the establishment of ReCAAP. Following this, section 3 analyses the framework of ReCAAP, with a focus on the crime that is targeted in the agreement, as well as the system and function of the Information Sharing Centre (ISC). Finally, section 4 studies the impacts of ReCAAP and concludes the article.

\section{Background of the Establishment of ReCAAP}

\subsection{The Situation of the Malacca/Singapore Straits}

Geopolitically, the Malacca and Singapore Straits primarily fall under three different territorial and maritime jurisdictions, namely Indonesia, Malaysia, and Singapore. ${ }^{6}$ Historically, the straits were important for both regional and global maritime trading networks because the straits link ports in Europe, eastern Africa, and the Arabian Peninsula, with key trade centres in the States of Southeast Asia and East Asia. ${ }^{7}$ According to Freeman, the straits began to be used for international trade two millennia ago, when Rome replaced Greece. ${ }^{8}$ Since then, the straits have been crucial for not only local Asian people but also European people, especially the Dutch and British East India Companies. ${ }^{9}$

As maritime transportation became increasingly important, so too did the Malacca and Singapore Straits. Currently, the straits are crucial for oil shipping to China and Indonesia, two of the world's fastest-growing economies. ${ }^{10}$

6 Felipe Umaña, Threat Convergence: Transnational Security Threats in THE Straits of MALACCA 4 (2012) (suggesting that Thailand can be a coastal State for the Malacca Strait, if the Strait is broadly defined). See generally Tara Davenport, Southeast Asian Approaches to Maritime Boundaries, 4 Asian Journal of International LAW 309, 32O-21 (2014) (discussing disputes on maritime delimitation).

7 Peter Borschberg, The Singapore and Melaka Straits: Violence, Security AND Diplomacy in THE 17TH CENTURY 1 (2O10).

8 Donald B. Freeman, The Straits of Malacca: Gateway or Gauntlet? 69 (2OO3).

9 Nordin Hussin, Trade and Society in the Straits of Melaka: Dutch Melaka and English Penang, 1780-1830, at xx-xxi (2007).

10 U.S. Energy Information Administration, World Oil Transit ChokePOINTS 6 (2017), https://www.eia.gov/beta/international/analysis_includes/special_topics/ 
Furthermore, the Straits have become fundamental for Japan,11 as almost 8 o percent of Japan's oil import trade from the Middle East travels through the Straits of Malacca. ${ }^{12}$

Nevertheless, the straits are widely perceived as being unsafe. In particular, following the 1997 Asian financial crisis, the number of pirates and armed robberies against ships increased, as attested to in the chart shown below. This may be because of the overthrow of Indonesia's Suharto regime, which caused rampant unemployment, political instability, and tighter fiscal policy. As a result, poverty prevailed throughout Southeast Asia, and therefore, people in coastal regions were motivated to become pirates for survival. ${ }^{13}$ In addition to this, over-fishing and pollution could have also motivated suffering fishermen to become pirates. ${ }^{14}$ It is worth noting here that 66 percent of the reported piracy and armed robbery against ships on the global scale occurred in Southeast Asia between 1991 and 2002. ${ }^{15}$

There are three possible reasons for such a large number of incidents. First, the Malacca and Singapore Straits are the primary chokepoint, with an estimated 16.0 million barrels flow per day in $2016 .{ }^{16}$ Therefore, it is relatively easy for criminal groups to attack oil tankers or other cargo vessels navigating through the straits. Second, criminal groups often coordinate their attacks across international borders so that the authority of each coastal State cannot effectively police their waters. ${ }^{17}$ For similar reasons, the undelimited area in the region can also be targeted by such groups. Third, the navy and coast guards of coastal States do not have the capacity to guard such vast maritime

World_Oil_Transit_Chokepoints/wotc.pdf.

11 Freeman, supra note 8, at 111-22 (describing the importance of the Malacca and Singapore Strait to Japan).

12 Siti Zubaidah Ismail \& Mohd Azizuddin Mohd Sani, The Straits of Malacca:Regional Powers Vis-à-vis Littoral States in Strategic and Security Issues and Interests, in Proceedings of the Seminar on National Resilience: Political Management and Policies in Malaysia Held on 13-15 July 2010 in LangKaWi 83, 90 (2010), http://repo.uum .edu.my/3169/1/S5.pdf.

13 S. Whitman \& C. Suarez, Dalhousie Marine Piracy Project: The Root Causes and True Costs of Marine Piracy (Marine Affairs Program Technical REPORT \#1) 12-13 (2012), https://cdn.dal.ca/content/dam/dalhousie/pdf/faculty/science/ marine-affairs-program/Technical_series/MAP\%2oTechnical\%2oReport\%20\%231.pdf.

14 Joyce Dela Pena, Maritime Crime in the Strait of Malacca: Balancing Regional and ExtraRegional Concerns, 10 Stanford Journal of International Relations 1, 3 (2009).

16 U.S. Energy Information Administration, supra note 10, at 6.

17 Whitman \& SUAREZ, supra note 13 , at 13. 
TABLE 1 Number of piracy and armed robbery incidents against ships in the Malacca and Singapore Straits, as well as their surrounding territorial waters, between 1993 and 2006 (made by the author on the basis of ICC-Iмв Piracy and Armed Robbery against Ships Annual Report 2004 and 2009)

\begin{tabular}{lrrrrrrr}
\hline Year & 1993 & 1994 & 1995 & 1996 & 1997 & 1998 & 1999 \\
\hline $\begin{array}{l}\text { Indonesia } \\
\text { Malacca Straits }\end{array}$ & 10 & 22 & 33 & 57 & 47 & 60 & 115 \\
Malaysia & 5 & 3 & 2 & 3 & & 1 & 2 \\
Singapore Straits & & 4 & 5 & 5 & 4 & 10 & 18 \\
\hline Year & & 3 & 2 & 2 & 5 & 1 & 14 \\
\hline Indonesia & 2000 & 2001 & 2002 & 2003 & 2004 & 2005 & 2006 \\
Malacca Straits & 119 & 91 & 103 & 121 & 93 & 79 & 50 \\
Malaysia & 75 & 17 & 16 & 28 & 37 & 12 & 11 \\
Singapore Straits & 21 & 19 & 14 & 5 & 9 & 3 & 10 \\
\hline
\end{tabular}

areas. Corruption, which is serious in the region, could further exacerbate their performance. ${ }^{18}$

\subsection{The Drafting Process of ReCAAP}

As shown above, while the Malacca and Singapore Straits are important for Japan, they became more unsafe after the Asian financial crisis in 1997. As some Japanese-related vessels, including the MV Tenyu and MV Alondra Rainbow, were attacked in 1998 and 1999, respectively, ${ }^{19}$ it was essential for Japan to make the strait safer. However, as the strait is part of the coastal States, it was difficult for Japan to improve the situation alone. Therefore, Japan tried to establish a framework of cooperation in order to tackle piracy problems.

For this purpose, Japanese Prime Minister Obuchi proposed the establishment of a system for joint patrol and information exchange among coast guards at the 1999 ASEAN +1 summit. ${ }^{20}$ In 2000, the Japanese Government hosted the

18 Łukasz Stach, Neverending Story? Problem of Maritime Piracy in Southeast Asia, 7 International Journal of Social Science \& Humanity 723, 724-25 (2017).

19 Lindsay Black, Japan's Maritime Security Strategy: The Japan Coast Guard And Maritime Outlaws 117-19 (2014).

20 Present State of the Piracy Problem and Japan's Efforts, Ministry Foreign Aff. Japan (Dec. 2001), https://www.mofa.go.jp/policy/piracy/problemo112.html. 
"Regional Conference on Combating Piracy and Armed Robbery against Ships", which adopted the following three documents: (1) Asia Anti-Piracy Challenges 200o, (2) Model Action Plan, and (3) Tokyo Appeal. ${ }^{21}$ The following year, at the 2001 ASEAN + 3 summit in Brunei, Prime Minister Koizumi proposed establishing a working group of governmental experts to consider the formulation of a regional cooperation agreement related to antipiracy measures. ${ }^{22}$

Based on this proposal, from 2002, the ASEAN Member States, Bangladesh, China, India, Japan, Republic of Korea, and Sri Lanka, initiated negotiations to formulate an Agreement. After much negotiation, the agreement was eventually concluded on 11 November 2004. Then, on 4 September 2006, with the ratification of India as the tenth Contracting Party, the ReCAAP entered into force (including the following 14 States: Bangladesh, Brunei, Cambodia, China, India, Japan, South Korea, Laos, Myanmar, Philippines, Singapore, Sri Lanka, Thailand, and Vietnam) and the ReCAAP's IsC was established. ${ }^{23}$

Although the ReCAAP entered into force as a result of its acceptance by States that were required according to Article 18(3), other important States (namely, the coastal States of the Malacca and Singapore Straits, Indonesia, and Malaysia) had not ratified the agreement. There seem to be three possible reasons for this. First, two States were concerned that the acceptance of the United States (US) or other external States' cooperation would infringe upon their sovereignty. In particular, there was a worry that the presence of US marines in the Malacca Straits would encourage terrorism. ${ }^{24}$ Second, they were not satisfied with the agreement, especially on account of Singapore being the

21 Japan's Efforts to Combat Piracy and Armed Robbery Against Ships, Ministry Foreign AFF. JAPAN (Nov. 2001), https://www.mofa.go.jp/region/asia-paci/asean/relation/piracy .html; but see Ismail \& Sani, supra note 12, at 94-95. Although Japan led the discussion to conclude the ReCAAP, it is pointed out that Japan has basically focused on civilian cooperation and refrained from directly utilizing its maritime self-defense forces in the region. This is because Japanese military forces in this area is a sensitive issue, as Japan occupied this region during World War II.

22 Present State of the Piracy Problem and Japan's Efforts, supra note 20.

23 ReCAAP ISC, Commemorating a Decade of Regional Cooperation 20062016, at 33 (2016), http://www.recaap.org/resources/ck/files/corporate-collaterals/10\%20 ann\%2ocomm\%2obook.pdf.

24 Carrie R. Woolley, Piracy and Sovereign Rights: Addressing Piracy in the Straits of Malacca Without Degrading the Sovereign Rights of Indonesia and Malaysia, 8 SANTA CLARA Journal of International LAW 447, 449 (2010); see also Lindsay Black, Navigating the Boundaries of the Interstate Society: Japan's Response to Piracy in Southeast Asia, in Decoding Boundaries in Contemporary Japan: The Koizumi AdministraTION AND BEYOND 79, 84-85 (Glenn D. Hook ed., 2011). 
depositary of the ReCAAP and host of the ISc. ${ }^{25}$ It is said that Malaysia considers the ReCAAP an unnecessary competitor of the International Maritime Bureau's (Iмв) Piracy Reporting Centre that is located in Kuala Lumpur. ${ }^{26}$ Third, they may have been concerned that the ReCAAP ISC would publish reports that were unfairly critical of them, as the IмB Piracy Report Centre had done, according to Indonesia. ${ }^{27}$

\section{3}

\section{The ReCAAP Framework}

While the United Nations Convention on the Law of the Sea (UNCLOS) is regarded as a constitution for the Ocean, ${ }^{28}$ it also allows State parties to make a specific agreement, unless it is compatible with UNCLOS (Article 311). Although the ReCAAP seems highly relevant to the UNCLOs, it does not contradict it. Article 2 of the ReCAAP manifestly provides that "(n)othing in this Agreement shall affect the rights and obligations of any Contracting Party under the international agreements to which that Contracting Party is party, including the UNCLOS, and the relevant rules of international law".

\section{1 $\quad$ Targeted Crimes}

Given the aforementioned fact, it is quite understandable that the ReCAAP defined piracy similarly to UNCLOS. The definition of piracy in Article 1(1) of the ReCAAP is as follows:

(a) any illegal act of violence or detention, or any act of depredation, committed for private ends by the crew or the passengers of a private ship or a private aircraft, and directed:

(i) on the high seas, against another ship, or against persons or property on board such ship or

(ii) against a ship, persons or property in a place outside the jurisdiction of any State.

25 See Noraini Zulkifli, Sharifah Munirah Alatas \& Zarina Othman, The Importance of the Malacca Straits to Japan: Cooperation and Contributions Toward Littoral States, 41 Malaysian Journal of History, Politics \& Strategic Studies 8o, 94 (2014).

26 Sam Bateman, Regime Building in the Malacca and Singapore Straits: Two Steps Forward, One Step Back, 4 The Economics of Peace \& Security Journal 45, 48 (2009).

27 John F. Bradford, The Growing Prospects for Maritime Security Cooperation in Southeast Asia, 58 Naval War College Review 63, 69 (2005).

28 Elisabeth Mann Borgese, A Constitution for the Oceans, in The Tides of Change: Peace, Pollution, and Potential of the Oceans 340, 340 (Elisabeth Mann Borgese \& David Krieger eds., 1975). 
(b) any act of voluntary participation in the operation of a ship or of an aircraft with knowledge of facts making it a pirate ship or aircraft;

(c) any act of inciting or of intentionally facilitating an act described in subparagraph (a) or (b).

The sole difference from UNCLOS is the targeting of piracy as stated in (a)(i). While piracy under UNCLOS includes violence against aircraft, piracy under the ReCAAP does not. Given that the aircraft has never been a target of pirates since the adoption of UNCLOS, ${ }^{29}$ and the agreement was adopted to secure a sea lane, it is reasonable to focus on maritime piracy and not air piracy.

One of the most distinguished achievements of the ReCAAP is the introduction of "armed robbery against ships" into treaty law. As its definition reveals, piracy can occur only on the high seas; therefore, it is said that international law, which is reflected in provisions of UNCLOS, cannot appropriately react to maritime violence, as they often occur within the territorial waters of vulnerable States. ${ }^{30}$ Diaz and Dubner argue that "the expanded definitions of piracy and armed robbery are necessary in order to cover acts occurring while ships are berthed or anchored within the 'territorial' waters of a state rather than on the "high seas". ${ }^{31}$

In fact, even before the ReCAAP was adopted, both International Maritime Organization (IMO) and Iм в used the expression of "armed robbery against ships in non-legal documents". This expression publicly began to be used in the Draft Code of Practice for the Investigation of the Crimes of Piracy and Armed Robbery against Ships in 2000 at the Iм0. ${ }^{32}$ Then, Імв incorporated the definition into the practice of the Piracy Reporting Centre. ${ }^{33}$ This Centre collects information from shipping and insurance companies, and broadcasts it to

29 Edward McWhinney, Aerial Piracy and International Terrorism: The Illegal Diversion of Aircraft and International LaW 5-6, n.1 (2d ed. 1987) (indicating the difficulty of applying Article 15 of the $195^{8}$ High Seas Convention, which defines piracy in the same way as unCLOs, to aerial piracy).

$30 \quad$ Rosemary Collins \& Daud Hassan, Applications and Shortcomings of the Law of the Sea in Combating Piracy: A South East Asian Perspective, 40 Journal of Maritime LaW \& Commerce 89, 97-98 (2009).

31 Leticia M. Diaz \& Barry Hart Dubner, An Examination of the Evolution of Crime at Sea and the Emergence of the Many Legal Regimes in Their Wake, 34 North Carolina JournaL of international LaW \& Commercial Regulation 521, 535 (2009).

32 Int'l Maritime Org. [IMO], Msc/Circ.984, Draft Code of Practice for the Investigation of the Crimes of Piracy and Armed Robbery Against Ships (Dec. 20, 2000), http://docs.yasinskiy. net/books/imo-msc-circ/984.pdf.

33 Robert C. Beckman, Combatting Piracy and Armed Robbery Against Ships in Southeast Asia: The Way Forward, 33 Ocean Development \& International Law 317, 320 (2002). 
ships every day. ${ }^{34}$ Although these Iм в activities contribute to the global diffusion of the concept of "armed robbery against ships", such activities do not have much implication from the point of view of international law. This is because Ім В is a non-governmental organisation $(\mathrm{NGO})^{35}$ and cannot directly affect the will of States which are still crucial for making international legal rules. ${ }^{36}$ On this point, the official adoption of the Code of Practice for the Investigation of the Crimes of Piracy and Armed Robbery against Ships (Code of Practice) at the IMO, an intergovernmental organisation, is a milestone, ${ }^{37}$ because its Paragraph 2.2 provides a definition of "arms robbery against ships".

That being said, the Code of Practice is just a non legally binding instrument. Then, as a legally binding instrument, the ReCAAP first defined "armed robbery against ships". Article 1(2) of the ReCAAP describes this crime in the following manner: ${ }^{38}$

(a) any illegal act of violence or detention, or any act of depredation, committed for private ends and directed against a ship, or against persons or property on board such ship, in a place within a Contracting Party's jurisdiction over such offences;

(b) any act of voluntary participation in the operation of a ship with knowledge of facts making it a ship for armed robbery against ships;

(c) any act of inciting or of intentionally facilitating an act described in subparagraph (a) or (b).

In terms of elements of a crime, the only factor that distinguishes this from piracy is the place where the crime occurs. Since the geographical scope is described as "in a place within a Contracting Party's jurisdiction over such offences", it may be a little confusing. One possible interpretation would be to include violence which occurs in Exclusive Economic Zones (EEZ) within

34 IMB Piracy Reporting Centre, ICC Com. CRIME Servs., https://www.icc-ccs.org/piracy -reporting-centre (last visited Apr. 17, 2O21).

35 International Maritime Bureau, ICC Com. Crime Servs., https://www.icc-ccs.org/icc/ imb (last visited Apr. 17, 2021).

36 United Nations, Draft Conclusions on Identification of Customary InTERnational LAW, With CommentaRies 130-132 (2018), https://legal.un.org/ilc/ texts/instruments/english/commentaries/1_13_2018.pdf.

37 Int'l Maritime Org. [IMO], A. 922 (22), Code of Practice for the Investigation of the Crimes of Piracy and Armed Robbery Against Ships (Jan. 22, 2002), http://www.fortunes-de-mer .com/mer/images/documents\%2opdf/legislation/Internationale/Piraterie/OMI/ Resolution_A922_(22)_2001_RU.pdf.

38 Zhen Sun, Tenth Anniversary of the Regional Cooperation Agreement on Combatting Piracy and Armed Robbery Against Ships in Asia, 1 Asia-Pacific Journal of Ocean Law \& Policy 276, 276 (2016); Regional Cooperation Agreement on Combating Piracy and Armed Robbery Against Ships in Asia art. 1(2), Nov. 11, 2004, 2398 U.N.T.S. 199. 
this definition, because coastal States have jurisdiction over the maritime area. However, it should be noted that parties must have jurisdiction over such offences, namely acts of violence. Within EEZ, coastal States only have jurisdiction over artificial islands, marine scientific research, and the protection and preservation of the marine environment, which are not directly related to acts of violence. Moreover, as shown above, the ReCAAP was not drafted to give effect to the right and obligation under the UNCLOS. Therefore, this provision should not be interpreted to justify the creeping jurisdiction of coastal States. If we were to interpret, "in a place within a Contracting Party's jurisdiction over such offences" should mean internal, territorial, and possibly archipelagic waters. $^{39}$ This articulation is possibly introduced because the geographical scope of piracy is described as "a place outside the jurisdiction of any State" as well as high seas. Therefore, the current expression was introduced so that no gap between the two crimes is generated. ${ }^{40}$

\subsection{Information Sharing Centre (ISC)}

The ReCAAP established the ISC "to promote close cooperation among the Contracting Parties in preventing and suppressing piracy and armed robbery against ships (Article 4(1))". Part II of the ReCAAP is named the "Information Sharing Centre" and consists of five Articles, and Part III is titled "Cooperation through the Information Sharing Centre" and consists of three Articles. Given that the ReCAAP only has 22 Articles, ISC-related Articles make up one-third of the total volume. The ReCAAP's IsC is composed of the Governing Council, which consists of representatives from each Contracting Party, and the Secretariat, which is headed by the Executive Director (as stated in Article 4).

39 Actually, even non-flag States can exercise jurisdiction over piracy, which occurs beyond their territorial water, as shown above. Therefore, if coastal States have jurisdiction over the crime provided in Article 1(2) of the ReCAAP within their EEZ, it does not necessarily lead to creeping jurisdiction. However, States exercise such jurisdiction based on the universality principle and not as an EEZ coastal State. Therefore, in any event, "a place within a Contracting Party's jurisdiction over such offences" should not be interpreted to encompass the EEZ.

40 See Robert Beckman \& Monique Page, Piracy and Armed Robbery Against Ships, in The Handbook of Security 234, 239 (Martin Gill ed., 2d ed. 2014) (indicating that the Convention for the Suppression of Unlawful Acts Against the Safety of Maritime Navigation (suA Convention) can be a useful tool for combating both piracy and armed robbery against ships); see also Makoto Seta, A Murder at Sea Isn't Just a Murder: The Expanding Scope of Universal Jurisdiction Under the SUA Convention, in MARITIME Areas: Control and Prevention of Illegal Traffics at Sea 115, 119-23 (Patrick Chaumette ed., 2016) (discussing crimes under the sUA Convention). 
The ISC is comprised of four departments: operations, research, programs, and administration..$^{41}$

The following three pillars align the roles and activities of the ReCAAP's ISC: (1) Information Sharing, (2) Capacity Building, and (3) Cooperative Arrangements. The most important pillar is information sharing, as the name of ISC demonstrates. In order to facilitate information sharing, Contracting Parties are required to designate an internal agency, such as the coast guards or port authority, as a focal point that deals with armed robbery against ships within its jurisdiction, as well as information sharing with neighbouring focal points and the ReCAAP's ISC, where necessary (Article 9). ${ }^{42}$ In addition to making communication more smooth, the ReCAAP's ISC established its own methodology for classifying incidents. According to this classification, the significance of each incident is determined by considering the following factors: (1) the level of violence and (2) economic loss. ${ }^{43}$ Furthermore, in order to promote information sharing, the ReCAAP's ISC issues the following three publications: (1) Special Reports, which focus on specific topics or incidents; (2) Weekly Updates, which include the details of incidents reported by ReCAAP Focal Points; and (3) Periodical Reports (on a monthly basis), which keep stakeholders informed about the trends and developments in piracy and armed robbery against ships in Asia. Thanks to the establishment of this methodology, information sharing among Contracting Parties has been more timely and accurate. ${ }^{44}$

"Capacity building plays a complementary role to the information sharing pillar." ${ }^{45}$ Capacity building programs provided by the ReCAAP's ISC are of various types. Some programs, such as the Focal Point Senior Officers' Meeting, focus on the effective and efficient operation of information exchanges and suppression of criminals under the ReCAAP. ${ }^{46}$ Other programs, such as the Capacity Building Executive Program, facilitate international cooperation to

41 Sheldon W. Simon, Safety and Security in the Malacca Straits: The Limits of Collaboration, 7 Asian SECURITY 27, 37 (2011).

42 Joshua Ho, Combating Piracy and Armed Robbery in Asia:The ReCAAP Information Sharing Centre (ISC), 33 Marine Policy 432, 433 (2009).

43 ReCAAP ISC, Annual Report 2018: Piracy and Armed Robbery Against SHIPS IN AsIA 69-70 (2018), https://www.recaap.org/resources/ck/files/reports/annual/ ReCAAP\%2OISC\%2oAnnual\%2oReport\%202018.pdf.

44 ReCAAP ISC, EXecutive Director's Report 2018, at 12-13 (2018), https://www .recaap.org/resources/ck/files/corporate-collaterals/ED's_Report_2018_Hi-Res_FINAL .pdf.

$45 \quad I d$. at 16.

46 ReCAAP ISC Focal Point Senior Officers' Meeting 2018 in Seoul, South Korea, ReCAAP (Nov. 13, 2018), http://www.recaap.org/event/FPSOM_2018_in_Seoul_South_Korea/. 
fight against piracy and armed robbery against ships in a way that is broad enough to include non-member States, such as Indonesia and Malaysia. ${ }^{47}$

The ReCAAP's ISC has also engaged in Cooperative Arrangements. Since the ISC began to publish Executive Directors Reports in 2013, it has communicated with Indonesia and Malaysia at least every year. Although they are non-member States, the ReCAAP's ISC recognises them as essential strategic partners in the region. ${ }^{48}$ Moreover, the ReCAAP's Isc has signed a Memorandum of Understanding (MOU) for cooperation with some international organisations, such as the IMO and International Criminal Police Organization (INTERPOL). In addition to this, it also concluded similar agreements with private shipping associations, such as the Baltic and International Maritime Council (BIMCO), Asian Shipowners' Association (ASA), and the International Association of Independent Tanker Owners (INTERTANKo). ${ }^{49}$ Furthermore, the ISC occasionally organises forums, such as the Nautical Forum and the ReCAAP IsC Piracy and Sea Robbery Conference, to bring diverse stakeholders together and foster collaboration and dialogue among them. ${ }^{50}$

As fifteen years have passed since the ReCAAP entered into force, it now seems timely to review its achievement and challenges. ${ }^{51}$ When evaluating the ReCAAP, it is important to analyse it in terms of its intended purpose, that is, how it works to deter piracy and armed robbery against ships in the Asian Region. Additionally, this section aims to clarify how the ReCAAP has affected other regions.

47 Implementation of the 2nd Capacity Building Executive Programme on Combating Piracy and Armed Robbery Against Ships in Asia, Ministry Foreign AfF. JAPAN (June 1, 2018), https://www.mofa.go.jp/fp/msp/page23e_ooo522.html.

48 RECAAP ISC, supra note 23 , at 71.

49 Id. at 67.

$50 \quad$ Strategic Focus: Cooperative Arrangements, RECAAP, http://www.recaap.org/recaap-isc _strategic_focus (last visited Apr. 18, 2021).

51 See RECAAP, https://www.recaap.org/recaap15 (last visited Apr. 18, 2021) (stating that the ISC held the 15th Anniversary Symposium named "Enhancing Regional Cooperation: 15 years and beyond" on 18 March 2021). 


\subsection{Safe Navigation in the Region?}

Even after the ReCAAP was adopted, piracy and armed robbery against ships continue to occur in the Asian region. The number of incidents after 2006 is plotted in the table below.

Since its adoption, there were fewer incidents of piracy and armed robbery in the first half of the 2000s, but from 2010, the number increased once again. Considering this figure, it is difficult to conclude that the ReCAAP has been effective in its aim of decreasing the number of piracy and armed robbery incidents against ships. ${ }^{52}$ However, it can be said that the number has been fluctuating at a lower level compared with what it used to be.

The effectiveness of the ReCAAP's Isc can be confirmed by several incidents, including Hai Soon 12, an Oil Products Tanker under the flag of Cook Islands. On 7 May 2016, Hai Soon 12, carrying 4,0oo metric tons of Marine Gas Oil, departed from Singapore through the Southern Ocean. The next day, the ReCAAP's ISC received information that the shipping company had not been able to make contact with Hai Soon 12. Upon receiving this information, the ReCAAP's ISC immediately informed the Indonesian Maritime Security

TABLE 2 The number of piracy and armed robbery cases against ships in Malacca and Singapore Straits, as well as their surrounding territorial waters, from 2007 to 2018 (made by the author on the basis of ICC-Імв Piracy and Armed Robbery against Ships Annual Report 2009, 2014, 2018 and 202O)

\begin{tabular}{lrrrrrrr}
\hline Year & 2007 & $\mathbf{2 0 0 8}$ & $\mathbf{2 0 0 9}$ & $\mathbf{2 0 1 0}$ & $\mathbf{2 0 1 1}$ & $\mathbf{2 0 1 2}$ & $\mathbf{2 0 1 3}$ \\
\hline Indonesia & 43 & 28 & 15 & 40 & 46 & 81 & 106 \\
Malacca Straits & 7 & 2 & 2 & 2 & 1 & 2 & 1 \\
Malaysia & 9 & 10 & 16 & 18 & 16 & 12 & 9 \\
Singapore Straits & 3 & 6 & 9 & 3 & 11 & 6 & 9 \\
\hline Year & $\mathbf{2 0 1 4}$ & $\mathbf{2 0 1 5}$ & $\mathbf{2 0 1 6}$ & $\mathbf{2 0 1 7}$ & $\mathbf{2 0 1 8}$ & $\mathbf{2 0 1 9}$ & $\mathbf{2 0 2 0}$ \\
\hline Indonesia & 100 & 108 & 4 & 43 & 36 & 25 & 26 \\
Malacca Straits & 1 & 5 & 0 & 0 & 0 & 0 & \\
Malaysia & 24 & 13 & 7 & 7 & 11 & 11 & 4 \\
Singapore Straits & 8 & 9 & 2 & 4 & 3 & 12 & 23 \\
\hline
\end{tabular}

52 Stach, supra note 18 , at 727 (arguing that "[c]omplete eradication of maritime piracy in Southeast Asia seems impossible at the moment"). 
Agency (BAKAMLA), who in turn shared the information with the Indonesian Navy (TNI-AL). Then, on 9 May, TNI-AL vessels intercepted and boarded Hai Soon 12 and arrested nine perpetrators on board. In this incident, the ReCAAP's ISC worked very effectively and contributed to the arrest of the perpetrators by sharing information with the regional authorities. ${ }^{53}$

\subsection{Participation of Non-Asian States}

Since the ReCAAP was concluded for the purpose of promoting cooperation among the Asian States, Article 18(1) of the ReCAAP limits the original Contracting Parties to sixteen Asian States, namely, Bangladesh, Brunei Darussalam, Cambodia, China, India, Indonesia, Japan, South Korea, Laos, Malaysia, Myanmar, Philippines, Singapore, Sri Lanka, Thailand, and Vietnam. However, paragraph 5 of the same Article states that "(a)fter this Agreement has entered into force, it shall be open for accession by any State not listed in paragraph 1". Therefore, even non-Asian States have been able to become members since 4 September 2006.

In fact, several Maritime Powers have already ratified the agreement. Beginning with Norway's ratification in 2009, the Netherlands and Denmark ratified it in 2010, the United Kingdom in 2012, Australia in 2013, and the US in 2014. The participation of these maritime powers has two significant implications. First, thanks to their power, the ReCAAP has been strengthened, for example, through their financial contribution. Although the expenses of the ISC are mainly provided by voluntary donations from Contracting Parties (Article 6 of the ReCAAP), Norway contributed 131,340 Singapore Dollars in 2018, the US contributed 69,00o Singapore Dollars, and the Netherlands contributed 32,178 Singapore Dollars (their contributions are ranked in 4th, $7^{\text {th }}$ and 8th place, respectively). Furthermore, these States can also support other Contracting Parties in the form of capacity building. For example, Australia convened the Focal Points Senior Officers Meeting in 2015, in which the experience of the Australian Maritime Border Command (Australian Focal Point) was shared. ${ }^{54}$

53 ReCAAP ISC, Annual Report 2016: Piracy and Armed Robbery Against Ships IN AsIA 28 (2016), https://www.recaap.org/resources/ck/files/reports/annual/annualre port2017.pdf. As shown above, ReCAAP ISC and two coastal States, Indonesia and Malaysia, have worked very closely. However, it is also indicated that the participation of these two States strengthens the ReCAAP framework; see Ian Storey, Maritime Security in Southeast Asia: Two Cheers for Regional Cooperation, in Southeast Asian Affairs 2009, at 36, 45 (Daljit Singh ed., 2009).

54 RECAAP ISC, ANNUAL REPORT 2015, at 26 (2015), https://www.recaap.org/resources/ ck/files/reports/2015/ReCAAPISCAnnualReport2015.pdf. 
Second, their participation can lead to the expansion of Contracting Parties to tackle "armed robbery against ships" (as previously mentioned, the ReCAAP was the first treaty to define this crime clearly). In addition, the ReCAAP obliges Contracting Parties to make every effort to take effective measures for preventing armed robbery against ships and arresting the suspects of the crime (Article 3). Moreover, Contracting Parties are expected to extradite the suspects of armed robbery against ships at the request of the other Contracting Party (Article 12) and render mutual legal assistance in criminal matters concerning armed robbery against ships (Article 13). Given the power of the navy and coast guard in the non-Asian Contracting Parties, their cooperation would lead to more effective and efficient suppression of piracy and armed robbery against ships. Furthermore, from the perspective of international law, the practice of non-Asian Contracting Parties could provide the basis of evidence to establish rules of customary international law. ${ }^{55}$ Given the fact that prevalent States' practices are needed to establish customary international law, the practice of these States is significant in establishing new customary rules that have their roots in the Asian region.

\subsection{Inspiration for the African Region}

The ReCAAP can also act as a model for other regions to implement similar rules. In fact, based on the ReCAAP, the Imo adopted a resolution which requires States in East Africa to adopt a similar agreement when piracy off the coast of Somalia became very serious. ${ }^{56}$ In order to discuss the conclusion of a new agreement to fight against piracy and armed robbery against ships, the IMO convened the conference in January 2009. In this conference, 21 governments of the Western Indian Ocean and the Gulf of Aden, and International Organizations, including the ReCAAP's Isc, were invited to Djibouti. ${ }^{57}$ There,

55 Otherwise, the rules can be a regional custom. See United Nations, supra note 36 , at $154^{-56 .}$

56 Int'l Maritime Org. [IMo], A. 1002 (25), Piracy and Armed Robbery Against Ships in Waters Off the Coast of Somalia, at art. 7 (Dec. 6, 2007), https://wwwcdn.imo.org/localresources/ en/KnowledgeCentre/IndexofIMOResolutions/AssemblyDocuments/A.10o2(25).pdf (no longer in force); Ved P. Nanda, Maritime Piracy: How Can International Law and Policy Address This Growing Global Menace?, 39 Denver Journal of International LaW \& Policy 177, 190 (2011) (suggesting that the IMO considered the ReCAAP to be a good model, even though the Resolution itself does not manifestly say that the ReCAAP should be a model); Joseph M. Isanga, Countering Persistent Contemporary Sea Piracy: Expanding Jurisdictional Regimes, 59 American University LAW Review 1267, 1308 (2010) (indicating that other regions should adopt a similar agreement to the ReCAAP).

57 Int'l Maritime Org. [IMo], C 102/14, Protection of Vital Shipping Lanes: Sub-regional Meeting to Conclude Agreements on Maritime Security, Piracy and Armed Robbery Against 
the "Code of Conduct Concerning the Repression of Piracy and Armed Robbery Against Ships in the Western Indian Ocean and the Gulf of Aden," also known as the Djibouti Code, was adopted. ${ }^{58}$

Unlike the ReCAAP, it is not a legally binding instrument, but as the Djibouti Code expressly stated in paragraph 9 of its preamble, it was inspired by the ReCAAP. ${ }^{59}$ Therefore, there are many similarities between the two instruments, including the definition of armed robbery against ships. Article 1(2) of the Djibouti Code defines armed robbery against ships in the following way:

(a) an unlawful act of violence or detention or any act of depredation, or threat thereof, other than an act of piracy, committed for private ends and directed against a ship or against persons or property on board such a ship, within a States internal waters, archipelagic waters and territorial sea (emphasis added);

(b) any act of inciting or of intentionally facilitating an act described in subparagraph (a).

This definition is not identical to that of the ReCAAP concerning the geographical scope of the crime. While the ReCAAP describes the scope as "in a place within a Contracting Party's jurisdiction over such offences", the Djibouti Code phrases it as "within a States internal waters, archipelagic waters and territorial sea". Basically, as shown above, the scope of the ReCAAP can be interpreted as having almost the same meaning as that of the Djibouti Code, though the latter is much clearer. This understanding of interpretations can be supported by the amendments of Paragraph 2.2 of the Code of Practice. As shown in section 3(a), the original version of Paragraph 2.2 of the Code of Practice is identical to the definition of armed robbery against ships under the ReCAAP. However, when the ReCAAP was amended in 2010, the definition was also modified and became identical to the definition in the Djibouti Code. ${ }^{60}$ Given that both the

Ships for States from the Western Indian Ocean, Gulf of Aden and Red Sea Areas Annex, at 2 (Apr. 3, 2009), http://www.fortunes-de-mer.com/mer/images/documents\%2opdf/ legislation/Internationale/Piraterie/OMI/Code\%2ode\%2oConduite\%2oDjibouti/ Resolution_C102-14_OMI_20o9_Djibouti_Code_RU.pdf.

58 See J. Ashley Roach, Countering Piracy Off Somalia: International Law and International Institutions, 104 AMERICAN Journal of InTERNATIONAL LAW 397, 410-11 (2010) (discussing the drafting history of the Djibouti Code).

59 Joshua Ho, Piracy Around the Horn of Africa, 1o ECHOGÉo 1, 8-9 (2009), http://journals .openedition.org/echogeo/1137o.

6o Int'l Maritime Org. [IMo], A. 1025 (26), Code of Practice for the Investigation of Crimes of Piracy and Armed Robbery Against Ships (Jan. 18, 2010), https://www.morkniga.ru/ files/shipowner/1597931556_A.1025(26)_-_Code_of_Practice_for_the_Investigation _of_the_Crimes_of_Piracy_and_Armed_Robbery_Aganst_Ships.pdf; Code of Conduct Concerning the Repression of Piracy and Armed Robbery Against Ships in the Western 
former and later versions of the Code of Practice were adopted to suppress the same crimes, this difference of expression does not necessarily lead to different conclusions. ${ }^{61}$

In addition, Article 8(1) of the Djibouti Code requires each participant to designate focal points, in order to suppress criminals and directly communicate with other focal points. However, there are some differences from the ReCAAP system. First, while the rules of the ReCAAP's ISC are established by spending one-third of all provisions of the ReCAAP, the Djibouti Code ISC does not detail such rules. Moreover, unlike the ReCAAP's IsC, which establishes the sole strong centre in Singapore, the Djibouti Code lists three centres in Kenya, Tanzania, and Yemen, for communication between focal points. Given that these three centres do not provide as much information as the ReAAP's ISC, such plural centres' system may be less effective.

Following the Djibouti Code's "Code of Conduct Concerning the Repression of Piracy, Armed Robbery against Ships, and Illicit Maritime Activity in West and Central Africa", the so-called Yaoundé Code was adopted in 2013, as the second instrument inspired by the ReCAAP. ${ }^{62}$ As its name suggests, this code was adopted to fight against piracy and armed robbery against ships at the Gulf of Guinea. ${ }^{63}$ Article 1(4) of the Yaoundé Code provides a definition of armed robbery against ships identical to that of the Djibouti Code. Moreover, Article 11(1) of the Yaoundé Code also requires each signatory to designate focal points. However, unlike the ReCAAP and the Djibouti Code, the Yaoundé Code neither designates nor establishes information sharing centres. Article 11(1) simply says, "(i)n order to ensure coordinated, smooth, and effective communication between their designated focal points, the Signatories intend to use the piracy information sharing centres (emphasis added)" without clarifying what are the piracy information sharing centres. After the adoption of the Yaoundé Code, the Maritime Trade Information Sharing Centre Gulf of Guinea (M TISCGOG) was established by the Oil Companies International Marine Forum

Indian Ocean and the Gulf of Aden art. 1(2), Jan. 29, 2009, https://au.int/sites/default/ files/documents/30848-doc-djibouti_code_of_conduct_o.pdf.

61 See Robin Geiss \& Anna Petrig, Piracy and Armed Robbery at Sea: The Legal Framework for Counter-Piracy Operations in Somalia and THE GULF OF Aden 74 (2011).

62 West and Central Africa Regional Agreements and Information Sharing, INT'L MAR. ORG., http://www.imo.org/en/OurWork/Security/WestAfrica/Pages/Code-of-Conduct-against -illicit-maritime-activity.aspx (last visited Apr. 19, 2021).

63 Ken Ifesinachi \& Chikodiri Nwangwu, Implementation of the Yaounde Code of Conduct and Maritime Insecurity in the Gulf of Guinea, 5 Research on Humanities \& Social SCIENCES 54, 59-62 (2015). 
as a pilot project in 2014. ${ }^{64}$ However, the MTISC-GOG was closed after the pilot project was successfully completed in 2016. Following this, France and the United Kingdom decided to establish Marine Domain Awareness for Trade Gulf of Guinea (MDAT-GoG) as the new maritime information network in the Gulf of Guinea by means of a virtual reporting centre. ${ }^{65}$

Thus far, 20 States from Eastern Africa have signed the Djibouti Code, ${ }^{66}$ and 25 States from Western and Central Africa have signed the Yaoundé Code. ${ }^{67}$ These agreements require them to suppress armed robbery against ships (Article 5 of the Djibouti Code and Article 7 of the Yaoundé Code). It can be concluded that State practice of policing and prosecuting armed robbery against ships, which originate from the Asian region, prevail in the African Continent. In addition, though the tasks and functions of ISC are diverse, the practice of designating national focal points are shared in all relevant documents, probably because such designation is helpful in the fight against piracy and armed robbery against ships.

\section{5}

\section{Conclusion}

It is difficult to determine whether the ReCAAP is a successful model from the perspective of numerical statistics, because although the number of piracy and armed robbery against ships initially decreased after the ReCAAP entered into force, it once again increased after a period of time. However, the ReCAAP should be deemed successful based on the following two perspectives. First, Contracting Parties of the ReCAAP seem satisfied with it. Even when the number of crimes increased around 2010, they did not consider amending the ReCAAP nor consider establishing a new alternative system. Second, as shown

64 Adeniyi Adejimi Osinowo, Combating Piracy in the Gulf of Guinea, 30 Africa SECURITY BRIEF 1, 4 (2015), https://africacenter.org/wp-content/uploads/2016/o6/ASB3oEN-Com bating-Piracy-in-the-Gulf-of-Guinea.pdf.

65 West and Central Africa Regional Agreements and Information Sharing, supra note 62.

66 Comoros, Djibouti, Egypt, Eritrea, Ethiopia, Jordan, Kenya, Madagascar, Maldives, Mauritius, Mozambique, Oman, Saudi Arabia, Seychelles, Somalia, South Africa, Sudan, Tanzania, Yemen and the United Arab Emirates; Djibouti Code of Conduct, InT'L MAR. Org., https://wwwcdn.imo.org/localresources/en/OurWork/Security/Documents/DCoC\% 2oNewsletter\%2O(2015).pdf (last visited Apr. 30, 2021).

67 Angola, Benin, Burkina Faso, Burundi, Cameroon, Cape Verde, the Central African Republic, Chad, Congo, Côte d'Ivoire, the Democratic Republic of the Congo, Equatorial Guinea, Gabon, the Gambia, Ghana, Guinea, Guinea-Bissau, Liberia, Mali, Niger, Nigeria, Sao Tome and Principe, Senegal, Sierra Leone, and Togo. 
in Section 4, the ReCAAP attracts non-Asian States and can be a good model for other regions, including Africa.

In this way, the international law that fights against piracy and armed robbery in ships has been developed by the Asian Region. Given that there is minimal Asian contribution to the development of international law otherwise, this fact is worthy of a special mention. However, dating back to the beginning of the 2oth century, there was a bud flush of this Asian contribution, through the so-called Matsuda Draft. Rapporteur Mr. Matsuda from Japan and Mr. Wang Chung-Hui from China prepared this draft as a work of the Sub-Committee on Suppression of Piracy, Committee of Experts for the Progressive Codification of International Law. ${ }^{68}$ The term 'private ends', that remains in the UNCLOS today, ${ }^{69}$ originated in this draft, meaning that it had a significant impact on the codification of the international law of piracy. ${ }^{70}$

Although this is just a contribution of two Asian experts and not of the Asian region itself, the experts were elected as members of the Sub-Committee because they are from Asia, which has much experience suppressing maritime crimes. As Indonesia is now suffering from illegal, unreported, and unregulated (IUU) fishing, they are attempting to criminalise such fishing. ${ }^{71}$ For that purpose, Indonesia held the International Symposium on Fishery Crimes and the 2018 Our Ocean Conference, in which IUU fishing was seriously debated. Given the Asian experience of establishing the framework to fight maritime crimes, this Indonesian initiative could lead to a new set of international legal rules in the fight against IUU fishing, if Indonesia successfully establishes the Asian framework from the start.

68 League of Nations Committee of Experts for the Progressive Codification of International Law, Questionnaire No. 6: Piracy, 2o American Journal of International LaW 222, 222 (1926).

69 Arron N. Honniball, The 'Private Ends' of International Piracy: The Necessity of Legal Clarity in Relation to Violent Political Activists 3 n.8 (2015), http://www.internationalcrimesdatabase.org/upload/documents/20151102 T10o953-Honniball\%2oICD\%2oBrief.pdf.

70 P. W. Birnie, Piracy: Past, Present and Future, 11 Marine Policy 163, 169 (1987).

71 Ema Septaria, IUU Fishing in Indonesia, Are ASEAN Member States Responsible For?, 11 International Journal of Business, EConomics \& LAW 76, 79-81 (2016). 


\section{Acknowledgements}

This work was supported by Konosuke Matsushita Memorial Foundation Research Grants (Grant Number 16-569) and JSPS KAKENHI (Grant Number ${ }_{17} \mathrm{~K}_{13} 619,19 \mathrm{~K} 13519$ and $\left.21 \mathrm{Hoo667}\right)$. This article is based on the presentation the author made to the Development of International Law in Asia (DILA) 3oth Anniversary International Conference held at the Indonesia Ministry of Foreign Affairs, Jakarta, Indonesia from 14 to 18 October 2019. 